\title{
INNOVATION WITHIN THE MORAVSKOSLEZSKÝ REGION - SMALL AND MEDIUM SIZED ENTERPRISES
}

\author{
Vendula FIALOVA², Pavlína HRONOVA ${ }^{3}$
}

\begin{abstract}
The paper focuses on innovation in the Moravian-Silesian Region in the sector of small and medium enterprises. The article presents the results of research which has dealt with innovations in the sector of small and medium-sized enterprises, in particular with types of innovations which have been implemented in this sector. Furthermore, it evaluates the impacts of their implementation on selected areas and how the size of a company influences the effects of implemented innovations within the selected areas. The greatest influences from the point of view of the effect of implemented innovation have been discovered in criteria focused on the observation of the market and a less significant influence in a criterion focused on social sector.
\end{abstract}

\section{KEY WORDS}

Innovation, competitivness, knowledge economy

JEL

Jel: 031.

\section{INTRODUCTION}

Current influences on business are representeded by such characteristics as variability, turbulence, dynamics, intellectualization, informatization and increasing competition. Success is not guaranteed in such conditions.

The basic prerequisite for a successful operation of a company in a market and its maintaining a competitive edge is the active and systematic approach to promoting corporate innovation activities and the implementation of innovation itself.

The fundamental basis for the selected issue is a reflection based on the fact that the existence of each company, regardless of its size and scope of its business, is not isolated. Every business is,

\footnotetext{
${ }^{2}$ Ing. Vendula Fialová, +420 595228 107, Vysoká škola podnikání a práva, a.s., Michálkovická 1810/181, 710 00 Ostrava - Slezská Ostrava, Czech republic, vendula.fialova@vspp.cz, vspp.cz.

${ }^{3}$ Ing. Pavlína Hronová, +420 595228 132, Vysoká škola podnikání a práva, a.s., Michálkovická 1810/181, 710 00 Ostrava - Slezská Ostrava, Czech republic, pavlina.hronova@vspp.cz, vspp.cz.
} 
within its activities, a part of a business community and currently in an environment of strong market competition (Veber, Srpová 2005).

The aim of this paper is to present the results of research focused on innovation in small and medium enterprise - specifically to determine which innovations are implemented in this area, what the effects of their implementation are in selected areas and to determine whether the effects of implemented innovations have an impact on the size of an enterprise in selected areas.

The implementation has taken the form of research; data collection has been carried out with the use of the method of questioning, and the obtained primary data have been processed with the use of statistical analysis - dependance analysis using the Spearman correlation test.

\section{CURRENT CONCEPT OF ECONOMY}

Developed economies are currently characterized as societies that build their competitiveness primarily on knowledge. At present, these societies are generally perceived as knowledge societies. An interesting concept was put forth by (Vlk 2006) - it is a society where the process of creation plays the biggest role in the accumulation of wealth, or according to Fischel, our society has been society of knowldge and understanding since the beginning of our history. (Vlk 2006) further mentions that according to Ježek, the fundamental questions asked in a knowledge society are not only questions ,what" but ,why" and ,how". At present, it is an almost undeniable fact that the ability to innovate and capitalize on the results of knowledge and science is of extreme importance for companies or a society (Vlk 2006).

The competitive ability of enterprises or societies is defined as the ability to show steady growth in productivity; i.e. to achieve higher outputs with limited inputs of labour and capital.

In a broader sense, competitiveness can be perceived as a set of conditions for achieving long-term performance and growth. This is the basis for increased economic equilibrium in terms of internal and external balance. The competitive ability of a company is also manifested in the form of gaining and maintaining or increasing market share at the national and international market. (Kislingerová et al. 2008).

(Kislingerová 2011) also states that the basic competitive advantage of an economy in the concept of "knowledge economy" then becomes an "innovation potential" allowing a relevant business system to constantly come up with such changes in the societal cooperation that make the product more marketable than the product of other firms, corporations, regions and possibly countries.

It has been statistically proven that the level of education and knowledge in a society has a direct correlation with the ability to successfully develop innovation.

\section{THE CONCEPT OF INNOVATION}

The concept of innovation has its roots in Latin. It comes from the Latin word "innovare" which can be translated as "to restore". The Czech language offers more options to convey the meaning of the term e.g.:"change", "introduce something new". Upon closer reflection it might be possible to find other options. How are we, in reality, going to define: What is a "restoration or renewal"? What constitutes a "change"? What does "something new" look like?

Today, innovation is considered to be a factor which significantly affects the competitiveness of companies as well as countries or their regions. 
Milan Zelený has defined innovation as follows: "Innovation is such a quantitative and qualitative improvement of a product, process, or business model that it will significantly add value to the customer and enterprise, ideally both at the same time. If the added value is realized through a transaction; innovation itself arises in the market at the time of sale. Actually, it is realized by the customer. Therefore, innovation is fundamentally different from invention, patent or improvement proposal - these may remain unrealized, in a vault, hidden away in a warehouse or the patent office in the form of papers. "(Košturiak, Chala 2008).

(Narayanan, Colarelli O'Connor 2010, p. 89) define innovation as a new idea, method, process or device that provides a higher degree of performance for the user. Change caused by the fact that innovation has been applied typically adds value for the customer or the manufacturer.

(Baldwin, Gellatly 2003, p. 2) hold that - innovation is the commercialization of knowledge in the form of new or improved products, processes or combinations thereof. Rasheed (2012) points out that innovation is a key factor in the ability to predict the revolutionary changes in development.

According to Jacobsen (2006) innovations do not constitute, as it is often assumed, only the development of completely new product or service; it is rather a modification of existing products and services; the securing of new markets or finding new uses for products already in existence. It is a new combination of already existing factors, more competitive production, other distribution or market determination of products or the transfer of business models from one area to another. This is essentially an activity characterized by transfer, transfer being essential aspect.

There exist different views for the definition of innovation. Is it just a question of technologies? Or is it the process of change? Innovation can be termed as the application of creativity in order to solve a problem and the takeing adavantage of opportunities. Innovation refers both to the final product, as well as its production process. In connection with innovation, creativity plays an important role. What is a mutual bond between them? Creativity is about "thinking" and innovation about "doing" (Kirby 2009).

It is obvious that innovation is closely related to creativity and creative thinking. Creative thinking can be seen as a process, which, however, does not take place without preparation. At the same time it has its structure and relation to critical thinking. In other words, the interaction of these components makes sense (Dytrt, Stř́teský 2009). Innovation and creativity in the workplace have become increasingly important determinants of organizational performance, success, and longerterm survival. (Anderson, Potocnik, Kristina, Zhou 2014).

Innovation involves the convertion of new knowledge into new products, processes or services and then its real application of this new product, process or service. The standard viewing of innovation can be called "technological pressure", which means new knowledge defined by technologists and researchers. An alternative approach to innovation can be characterized as "pull of the market", which reflects a view of innovation beyond invention, and highlights the user, not the manufacturer as the representative of the source of major innovations (Johnson, Whittington, Scholes 2011).

The interpretation of innovation, especially by the public, still presents a number of inaccuracies. Innovations have been perceived for a number of years as a direct result of research and development activities. The actual design and implementation of innovation was associated with the so-called linear model (currently, innovation is associated mainly with the non-linear model), under which innovations are implemented through a sequence of several distinct phases. The initial phase presents basic research, followed by applied research, the development and research of a prototype; 
the sequence is concluded by a commercialization phase and the introduction of innovation onto the market (Ministry of Education 2013).

The presented view on the identification and implemention of innovation has been subjected to increasing criticism since the 1980s. Discussions have mainly concerned two relatively opposing views on the level of motivation as the driving force towards the pursuit of innovation. The first view was based on the strong ties of innovation - research outputs, the second highlighted the fact that innovation was particularly influenced by the pressure of the market (demand, competition) or the mobilization of human resources in businesses. The result is a consensus that innovation does not occur only on the basis of a linear process, but that it is a model of interaction which includes the mutual cooperation of participating actors. Mutual cooperation significantly enhances the ability to create and shape new knowledge (Ministry of Education 2013).

The complexity of the innovation process and its complex divisibility into separate phases is illustrated by another approach to innovation. Innovations, as mentioned above, also include their own development of new products or processes as well as know-how which served as their source. Simply put - new products are the result of a combination of innovation on several levels, namely: - $\quad$ at the level of basic general (technological) knowledge or knowledge of new materials, etc., the use of which may be implemented after several years, often indirectly

- with specific new technologies,

- $\quad$ and on concrete, practical motives and knowledge that may be the first or last, but certainly a key impulse.

The complex nature of the innovation process and the significance of different sources of innovation was recognized throughout the 90 s not only by professionals and by the wider professional community during the first decade of this century. The evidence and output are new formulations of definitions in EU documents and other multinational organizations or changes in statistical investigations pursuing innovative activities (Ministry of Education 2013).

According to the new (wider) concept of innovations there are currently distinguished four main types of innovation (in accordance with the revised Oslo manual 2005):

Product innovation - represents the introduction of a new product or service possibly significantly improved with respect to their characteristics or intended use. This includes significant improvements in technical specifications, components and materials, software, user friendliness or other functional characteristics.

Process innovation - is the introduction of new or significantly improved production methods or supply methods. This includes significant changes in production techniques, equipment and / or software and distribution systems.

Marketing Innovation - is the implementation of a new marketing method which involves significant changes in product design or its packaging, product placement, product promotion or pricing.

Organizational innovation - is the implementation of new organizational practices in business activities, in the organization of a workplace or external relations within the organization in order to effectively use the innovation capacity of the company and increase its efficiency (ČSÚ 2013). This classification maintains the highest possible degree of continuity (ensures the comparability of data) with the previous definition of the technical innovation of a product and a process, which was used in the previous edition of the Oslo Manual 1997. 
The innovation of products and innovation of processes are closely related to the concept of the technical (technological) innovation of a product and technical innovation of a process. Marketing and organizational innovations extend the range of innovations covered by the manual and belong to non-technical (non-technological) innovations (ČSÚ 2013).

\section{PRELIMINARY RESEARCH - INNOVATION ACTIVITIES IN THE CZECH REPUBLIC AND THE MORAVIAN-SILESIAN REGION}

According to research The innovative activities of enterprises in the Czech Republic between 2010 2102 on the territory of the Czech Republic in selected sectors of the economy, $43.9 \%$ of enterprises out of the total number of economically active enterprises engaged in innovative activities. $35.6 \%$ of businesses introduced technical innovation and 31.6\% introduced non-technological innovation (CSO, 2014).

If we look at the structure of enterprises by size and ownership structure, the most innovative were large enterprises $(78.7 \%)$, they were followed by medium-sized enterprises $(57.6 \%)$ and the lowest share of innovations was achieved by small businesses $(38.2 \%)$.

In terms of ownership structure, foreign-owned enterprizes innovated more $(54,1 \%)$ than domestic companies $(41 \%)$.

Table 1: Share of innovative enterprises in the total number of enterprises by type of innovation activity

\begin{tabular}{|c|c|c|c|c|c|c|}
\hline & ČR & $\begin{array}{l}\text { Small } \\
\text { enterprizes }\end{array}$ & $\begin{array}{l}\text { Medium- } \\
\text { sized } \\
\text { enterprizes }\end{array}$ & $\begin{array}{l}\text { Large } \\
\text { enterprizes }\end{array}$ & $\begin{array}{l}\text { Domestic } \\
\text { enterprizes }\end{array}$ & $\begin{array}{l}\text { Foreign } \\
\text { affiliates }\end{array}$ \\
\hline \begin{tabular}{|l|} 
Innovative \\
enterprises in \\
total $(\%)$
\end{tabular} & 43.9 & 38,2 & 57,6 & 78,7 & 41,0 & 54,1 \\
\hline \begin{tabular}{|l} 
Technically \\
innovative \\
enterprises \\
$(\%)$ \\
\end{tabular} & 35,6 & 29,8 & 49,3 & 71,7 & 32,9 & 45,2 \\
\hline $\begin{array}{l}\text { Non } \\
\text { technically } \\
\text { innovative } \\
\text { enterprises } \\
(\%)\end{array}$ & 31.6 & 27,3 & 42,1 & 58,4 & 29,2 & 40,4 \\
\hline
\end{tabular}

Source: ČSÚ, 2014

In terms of regional breakdown, according to NUTS 2, the most innovate companies were in Central Moravia (47.4\% share of innovative enterprises), followed by Prague (45.1\%). Enterprises in Central Moravia also introduced the most technical innovations of all the regions.

In all the regions, enterprises were more dedicated to technical innovation rather than non-technical . In terms of businesses in the capital city of Prague, the proportion of those who introduced technical innovation $(34.8 \%$ ) was almost equal to the proportion of those that introduced nontechnological innovation (34.5\%). 
The least amount of innovation was carried out in the Southwestern (38,7 \%) and Moravia - Silesia $(42,6 \%)$ regions. The proportion of enterprizes introducing technical innovations in Moravia Silesia was $33,8 \%$ and the share of non - technical innovations was $30,9 \%$.

Table 2: Share of innovative enterprises in the total number of enterprises according to type of innovation activities in the regions NUTS2, 2010-2012

\begin{tabular}{|l|l|l|l|}
\hline Region & $\begin{array}{l}\text { Innovative enterprises } \\
\text { in total (\%) }\end{array}$ & $\begin{array}{l}\text { Technically innovative } \\
\text { enterprises (\%) }\end{array}$ & $\begin{array}{l}\text { Non-technically } \\
\text { innovative enterprises } \\
(\%)\end{array}$ \\
\hline Central Moravia & 47,4 & 38,6 & 32,9 \\
\hline Praha & 45,1 & 34,8 & 34,5 \\
\hline Southeast & 44,4 & 37,4 & 31,0 \\
\hline Northeast & 43,3 & 36,5 & 30 \\
\hline Southwest & 43,1 & 35,9 & 29,5 \\
\hline Central Bohemia & 42,6 & 34,1 & 32,0 \\
\hline Morava - Silesia & 42,6 & 33,8 & 30,9 \\
\hline Northwest & 38,7 & 31,0 & 27,6 \\
\hline
\end{tabular}

Source: ČSÚ, 2014

In the following research, we are going to have a closer look at the structure of innovation and the effects of implemented innovations in the Moravia - Silesia region.

\section{METHODOLOGY OF RESEARCH}

The research itself was preceded by the processing of research procedure, which included a selection of respondents, definition of the region, a selection of methods and techniques applied to the data collection and subsequent analysis.

The initial data for the basic sample of respondents represens the sectoral classification of economic activities - CZ-NACE (compliant with NACE rev.2 1. 1. 2009), section C - THE MANUFACTURING INDUSTRY. Said section includes production activities, but also activities related to the provision of services. The selected location was Moravskoslezský region.

A database of companies and institutions - the ALBERTINA database - was used to obtain basic data of businesses and institutions. This database provides basic and contact information of economic entities.

The research was carried out from June to August 2014 with the subsequent data and output analysis.

One of the requirements for statistical data processing is the representativeness of the sample; i.e. the representativeness of the selected set. Economic entities were selected based on the CZ-NACE classification, the principal criterion being their main activities.

Subsequently the division of the core set was carried out according to other criteria - namely the size of the company, legal status, ownership, region.

It is therefore a so-called. stratified sampling from an incomplete statistical survey because the survey has not been carried out within the selected set. 
Random selection, which enables to observe the randomness in the selection of specific respondents, was used.

A questionnaire was used as a technique for the collection of data. The obtained primary data was processed through statistical analysis - in particular, analysis of dependance using the Spearman correlation test was selected.

\section{RESULTS OF RESEARCH}

The research in question was focused on innovation in small and medium business - specifically to determine which innovations are implemented in this area, what are the effects of their implementation on selected areas and to determine whether it affects the size of the enterprise by the effects of implemened innovations within the selected areas.

Moravskoslezský region was the region selected for the research and it was necessary to select at least 30 respondents in order to meet the requirement of distinction between a „small set" and a „big set“" (Dorba 2010).

Based on the responses of respondents recorded within the pilot study, 1,100 respondents were interviewed.

Table 3: Returnability of questionnaire

\begin{tabular}{|l|l|}
\hline Number of respondents & 1100 \\
\hline Number of undelivered questionnaires & 45 \\
\hline $\begin{array}{l}\text { Number of discarded questionnaires - reluctance to } \\
\text { cooperate }\end{array}$ & 12 \\
\hline Number of addresses respndents & 1043 \\
\hline Number of returned questionnaires & 108 \\
\hline Real return & $10,35 \%$ \\
\hline
\end{tabular}

Source: own processing

In terms of statistical processing of the results of the questionnaire, respondents were addressed according to selected criteria, among which the following were included: company size (number of employees) and the core business (production and / or service).

The classification of respondents according to a selected viewpoint - line of business, was based on a methodology which is commonly used by e.g. the Czech Statistical Office.

Of the 87 respondents, 69 (i.e. $79,3 \%$ ) of them said the main line of business was production and 18 (i.e.20,7\%) of respondents said the main line of business was service delivery.

Enterprise size in terms of the number of employees was chosen as an additional criterion for the classification of respondents. The addressed respondents were, in accordance with the classification of the European Commission 1, broken down into micro, small and medium enterprises.

The following information was revealed based on the questionnaire - the majority of respondents represent enterprises with core business - manufacturing (79.3\%) and in terms of company size it is the small company category $(52.9 \%)$.

More than $50 \%$ of respondents pay attention to innovation activities (in this investigation innovative activity was not perceived as a final innovation). 
Respondents (93\%) who reported that they focused on innovative activities also stated that they had carried out a concrete innovation within a specified time period. The most reported type of an implemented innovation was product innovation, followed by process and organizational innovation and the least represented was marketing innovation. The largest group of respondents in terms of implemented innovations was represented by small businesses (11-50 employees).

In terms of the effects of implemented innovations to expand the product range, the majority of respondents stated a rather strong impact; with regards to the growth of market share, $86.42 \%$ of respondents said the influence was strong, rather strong and quite weak. In terms of sales growth, the majority of respondents $(60.49 \%)$ stated a strong effect and a rather strong effect, which also corresponds with the indicated impact on profit growth area (59.26\%). In terms of impact on the creation of new jobs, the majority of respondents stated that the influence was rather feeble $(72.84 \%)$.

Another phase of the research was aimed at determining whether there is a correlation between the effects of implemented innovations within selected areas and business size. The following areas were selected:

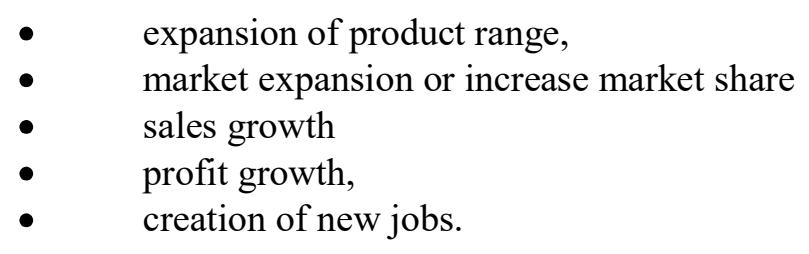

A separate test was carried out for each area.

Research question: Does the size of a business influence the effects of implemented innovations?

Hypothesis H0: $\quad$ Effects of implemented innovations do not depend on company size.

For each area a separate test carried out. Outputs for each area are given within the text below.

Table 4: The outputs of statistical analysis

\begin{tabular}{|l|l|l|}
\hline Hypothesis & Acceptance / rejection of the hypothesis & $\begin{array}{l}\text { Dependence / } \\
\text { independence between } \\
\text { variables }\end{array}$ \\
\hline $\begin{array}{l}\text { Effects of } \\
\text { implemented } \\
\text { innovations do not } \\
\text { depend on company } \\
\text { size. }\end{array}$ & $\begin{array}{l}\text { Product range - not rejected } \\
\text { Market share - rejected } \\
\text { Revenue growth - rejected } \\
\text { Growth in income - rejected } \\
\text { Creation of new jobs - rejected }\end{array}$ & the overall assessment. \\
\hline
\end{tabular}

Source: own processing

Based on the analysis of obtained outputs, the following can be stated: in terms of examining the impact of effects of implemented innovations on the development of the company in selected areas, very weak to moderately weak dependence was identified; very weak dependence was identified in the criteria - expanding the product range, weak dependence was identified in criteria - market share growth and job creation, moderately weak dependence was identified in economic indicators, namely sales growth and profit growth.

In summary, the most significant impact in terms of the effect of an implemented innovation was identified in the economic field; the least significant effect on criteria focusing on market monitoring and less significant effect on criteria focusing on the social area. 


\section{DISCUSSION}

The above statistical data showed that Moravia - Silesia is one of the regions with the lowest innovation activity both in technical and non-technical innovations. It is clear from the following research that innovative activities of enterprises play a vital role in the further development and businesses that innovate record specific effects in the economic field.

It is evident that most innovation takes place in product innovation in all the regions and regardless of company size.

It would be interesting to extend the research of innovative activities in the Moravian-Silesian Region to other aspects e.g: how innovative activities of enterprises differ in terms of individual sectors, size of companies and how innovative activities are linked to the sector in which the company operates. The next step would be a deeper look at individual types of innovations and their importance not only in the economic, but also in the social sector.

Given the number of different definitions of innovation which are mentioned in e.g. chapter 3, it is of utmost importance to define terminology and standardize methodology. This is one of the conditions of relevant research results and their comparability. A significant help in this regard in particularl is the methodology Manual OSLO (Oslo manual 2005).

\section{CONCLUSION}

The outcomes of the research show that the issue of innovation in small and medium enterprises is indispensable. It is undisputed that the area of small and medium-sized businesses has long-lasting dominance within society as a whole, not only in economic but also in social and societal issues.

Location selected for the implemented research (Moravian-Silesian region) was chosen because it is a region, which over the past twenty years has undergone extensive restructuring, which has significantly affected the overall development of the region itself. One of the major negative impacts of the afore-mentioned restructuring is high unemployment. Over the past five years this region has shown an increasing trend in the number of patent applications and has joined those regions where there is a relatively high number of such applications. It is also positive that this activity is mainly based on business practices and higher education environment. This fact corresponds to one of the outputs of the research i.e. - the highest number of implemented innovations is represented by product innovation. A significant impact in terms of the impact of an implemented innovation was identified in the economic area and less significant impact on the creation of new jobs. It follows that there is a significant potential for the realization of follow-up research activities, which may be focused on the importance of innovation in the social sphere.

\section{REFERENCES}

[1] Anderson, N., Potocnik, K., Zhou, J. (2014). Innovation and Creativity in Organizations: A State-of-theScience Review, Prospective Commentary, and Guiding Framework, Journal of Management, vol. 40, no.:5, pages 1297-1333.

[2] Baldwin, J.R. - Gellatly, G. (2003). Innovation Strategies and Performance in Small Firms. Cheltenham, UK: Edward Elgar. ISBN 1-84376-370-2

[3] Dytrt, Z. - Stř́teská, M. (2009). Efektivní inovace: odpovědnost v managementu. Vyd.1. Brno: Computer Press, 150 s. Praxe manažera. Business books. ISBN 978-80-251-2771-1.

[4] Jakobsen, L. K. (2006). Erfolgsfaktoren Bei Der Unternehmensgründung: Entrepreneurship in Theorie und Praxis. 1. Auf. Wiesbaden, ISBN - 10 3-8350-0379-8 
[5] Johnson, G. - Whittington R., - Scholes, K. (2011). Exploring strategy. Ninth edition. Edinburg: Pearson Education, 2011. ISBN 978-0-273-73202-0 101.

[6] Kirby, D. A. (2009). Enterpreneuership. Glasgow: Bell Bain,Ltd. ISBN 0077098387

[7] Kislingerová, E. a kol. (2008). Inovace nástrojů ekonomiky a managementu organizací. Vyd.1. V Praze:

C. H. Beck, 293 s. C. H. Beck pro praxi. ISBN 978-80-7179-882-8.

[8] Kislingerová, E. a kol. (2011). Nová ekonomika: nové př́ležitosti?. Vydání 1. V Praze: C. H. Beck, 322 s. Beckova edice ekonomie. ISBN 978-80-7400-403-2.

[9] Košturiak, J. - Chal', J. (2008). Inovace vaše konkurenční výhoda!. Brno: Computer Press. ISBN 978-80251-1929-7.

[10] Narayana, V. K. - Colarelli O'Connor, G. (2010). Encyclopedia of Technology and Innovation Management. Wiley John\&Sons. ISBN 978-1-405-16049-0.

[11] Rasheed, H. (2012). Innovation Strategy: Seven Keys to Creative Leadership and a Sustainable business model. Bloomington: Rasheed Howard ISBN 978-14697-8044-3

[12] Schüz, M. - Nový, I. - Kučera, D. (2015). Dlouhodobá podniková odpovědnost a etika v manažerském vzdělávání. Praha: Nakladatelství VŠE, OECONOMICA. ISBN 978-80-245-2121-3. [13] Veber, J. - Kotlasová, E. (1992). Management marketingu, inovací a kvality. Praha: Vysoká škola ekonomická. ISBN 8070799749, 9788070799741.

[14] Veber, J. - Srpová, J. (2005). Podnikání malé a střední firmy. Praha: Grada Publishing. ISBN 80-247-1069-2.

[15] Vlk, A. (2006). Jak dál v inovačním podnikání? In: Sborník př́spěvků z mezinárodní vědecké konference Znalostní ekonomika. ISBN 80-86754-63-9.

[16] Český statistický úřad, 2013 [online]. Praha: Český statistický úřad. Poslední změna 11. 4. 2013 [consulted: 11. 4. 2013]. Available from: http://www.czso.cz

[17] Český statistický úřad, 2014 [online]. Praha: Inovační aktivity podniků v ČR v letech 2010 - 2012. [consulted: 8.12. 2015]. Available from: http://www.czso.cz/csu/czso/inovacni-aktivity-podniku-v-cr-2010az-2012-up1r9kkmj3

[18] Dorba, M. 2010 [online]. Zpracování náhodného výběru - popisná statistika [online]. Ostrava:VŠB: Technická univerzita v Ostravě, [consulted: 2014-01-9]. Available from: homel.vsb.cz/ dor028/KMORII_1.pdf.

[19] Ministerstvo průmyslu a obchodu, 2013 [online]. Praha: Ministerstvo průmyslu a obchodu (C) 2005. [consulted: 25. 2. 2014]. Available from: http://www.mpo.cz/

[20] OECD, 2005 [online]. Oslo Manual: Guidelines for Collecting and Interpreting Innovation Data, 3rd Edition. [consulted: 5.12.2015]. Available from: www.oecd.org/sti/oslomanual 